\title{
Macular Alteration of Topical Diclofenac Sodium after Phacoemulsification Surgery in Diabetic Patients
}

\author{
Delfi Delfi*(D), Vanda Virgayanti(i), Julham Alandy \\ Department of Ophthalmology, Faculty of Medicine, Universitas Sumatera Utara, Medan, Indonesia
}



\section{Introduction}

Diabetes mellitus is one of the endocrine diseases characterized by elevation of blood glucose levels due to insulin impairment [1]. According to Riset Kesehatan Dasar, diabetes mellitus prevalence in 2007 was $1.1 \%$ and increased to $2.1 \%$ in 2013 . One of the most common microvascular complications of diabetes mellitus is diabetic retinopathy (DR) [2]. DR is a progressive microangiopathy characterized by damage and occlusion of small vessels. The first pathological changes are basal membrane thickening of retinal capillary endothelium, diminished pericytes, vessel dilatation, hard exudates, soft exudates, angiogenesis, retinal edema, and scarring [3], [4]. Cystoid macular edema (CME) was first reported by Irvine in 1953 and is one of the most serious complications of cataract surgery in a diabetic patient [5]. Diabetic patients having cataract surgery have an increased risk for developing CME postoperatively, especially if they are also diagnosed with DR [6].

Angiography CME was found 1-19\% after extracapsularcataractextraction ofphacoemulsification.
Almeida's study in 2011 stated that CME was significantly lower with the use of nonsteroidal antiinflammatory drugs (NSAID) prophylaxis continued with a combination of NSAID and corticosteroid for 4 weeks after phacoemulsification compared with the corticosteroid-only treatment [7]. NSAID's mechanism of action is inhibition of cyclooxygenase-1, cyclooxygenase-2, and endoperoxides. Inhibition of these enzymes also reduces macular thickening [8]. One of the most popular NSAID is diclofenac sodium eye drop. The objective of this study is to assess macular thickness alteration after the application of $1.00 \mathrm{mg}$ topical diclofenac sodium in diabetic patients who receive phacoemulsification surgery.

\section{Methods}

This was a quasi-experimental study that was conducted from June to November 2019 at Sumatera Utara University Hospital and Medan Baru Medical Centre Medan, Indonesia. DR patients who receive 
phacoemulsification surgery and intraocular lens (IOL) implantation were enrolled in this study. $\mathrm{HbA} 1 \mathrm{C}$ test performed before surgery and $\mathrm{HbA} 1 \mathrm{C}$ higher than $6.4 \%$ were included in this study. Exclusion criteria were glaucoma, intraocular inflammation, posterior segment disorder, laser photocoagulation history, and patients having intraoperative and post-operative complications of the surgery. The patients divided into two groups, the first group was treated with $1.00 \mathrm{mg}$ topical diclofenac sodium eye drop 3 times a day, starting 1 day before surgery for a month, and the second group was treated only with artificial tears eye drop after surgery. Ocular tomography coherence was performed at 1-day pre-phacoemulsification, 14 and 30 days postphacoemulsification. Macular thickness was analyzed using a paired t-test.

\section{Results}

The research subjects were cataract patients with type 2 diabetes mellitus who met the requirements to undergo phacoemulsification at the Medan Baru Eye Hospital (40 subjects). The research subjects were divided into two groups. One group was given artificial tears eye drops and the other group was given $1.00 \mathrm{mg}$ of diclofenac sodium eye drops postoperatively. Data were obtained from June to August 2019 by recording patient demographic data, $\mathrm{HbA} 1 \mathrm{C}$, visual examination, and macular thickness D-1 pre-cataract surgery, D+14, and D+30 after cataract surgery.

\section{Discussion}

Table 1 showed the characteristics of research subjects based on age. It is stated that most subjects aged more than 60 years old. This fact is not in line with the research of Kiziltoprak et al. and Becker et al. which stated that people with diabetes mellitus have a 5 times more risk of developing cataracts with the age range of 45-54 years [9], [10].

Table 1: Characteristics of research subjects by age

\begin{tabular}{lll}
\hline Age characteristics (years) & Frequency & $\mathrm{n}(\%)$ \\
\hline $41-<46$ & 1 & 2.5 \\
$46-<51$ & 1 & 2.5 \\
$51-<55$ & 10 & 25 \\
$56-<60$ & 6 & 15 \\
$>60$ & 22 & 55 \\
Total & 40 & 100 \\
\hline
\end{tabular}

In Table 3, it is revealed that the research subjects had $\mathrm{HbA} 1 \mathrm{C}$ levels with the highest frequency at $>10 \%$ levels. This level of $\mathrm{HbA} 1 \mathrm{C}$ can lead to the formation of mild-to-severe senile cataracts and NPDR with a predominance of mild types.
Table 2: Characteristics of research subjects based on gender

\begin{tabular}{lll}
\hline Gender & Frequency & $(\%)$ \\
\hline Male & 20 & 50 \\
Women & 20 & 50 \\
Total & 40 & 100 \\
\hline
\end{tabular}

In Table 4, the characteristics of research subjects based on the results of visual acuity showed that there are no statistically significant differences between pre-operative and post-operative visual acuity in the control group and the treatment group with a value of $p>0.005(p=0.0374)$.

Table 3: Characteristics of Research Subjects based on HbA1C

\begin{tabular}{lll}
\hline Levels & Frequency & $\mathrm{n}(\%)$ \\
\hline $7.0-8.0$ & 1 & 2.5 \\
$8.1-9.0$ & 1 & 2.5 \\
$9,1-10$ & 10 & 25 \\
$10+$ & 28 & 70 \\
Total & 40 & 100 \\
\hline
\end{tabular}

In this study, the macular evaluation was performed using optical coherence tomography (OCT). Walkden's research in 2017 stated SD-OCT to detect subclinical CME in patients having routine phacoemulsification and IOL insertion [11]. Bellocq's research in 2019 stated SD-OCT appears to be the procedure of choice for confirming the diagnosis CME [12].

Table 4: Overview of pre-operative visus at D-1 in the control and treatment groups

\begin{tabular}{|c|c|c|c|c|c|c|c|}
\hline Pre operation vision & \multicolumn{2}{|c|}{ Eye drop } & \multicolumn{2}{|c|}{ Diclofenac sodium } & \multicolumn{2}{|c|}{ Amount } & \multirow[t]{2}{*}{$\mathrm{p}$} \\
\hline Artificial tears & $\mathrm{n}$ & $\%$ & $\mathrm{n}$ & $\%$ & $n$ & $\% \%$ & \\
\hline Poor & 7 & 43.8 & 9 & 56.3 & 16 & 100.0 & 0.519 \\
\hline Worse & 13 & 54.2 & 11 & 45.8 & 24 & 100.0 & \\
\hline
\end{tabular}

In Table 5, a comparison of macular thickness a day before the surgery between control and treatment groups showed no significant difference. This is known with $p>0.05$, namely, at central 0.721 , inner 0.386 , and outer 0.688 . This indicates that there is no statistically significant difference in macular thickness. In Table 6 , the comparison of macular thickness at 1 day before surgery, 14 and 30 days after surgery in the control group shows no significant difference because the $p$-value appears to exceed $p>0.05$. In Table 7 , the comparison of the macular thickness at 1 day before surgery, 14 and 30 days after surgery in the treatment group shows a $p$ $<0.05$, that is, with a value of $p=0.008$ and $p=0.0001$. This study is in line with Yang in 2016 and Katsimpris in 2011 which stated that topical administration of diclofenac sodium can prevent thickening of the macula after phacoemulsification surgery in senile cataract patients with diabetes mellitus.

Table 5: Comparison of macular thickness in D-1 control and treatment groups

\begin{tabular}{llll}
\hline Macular thickness & $\mathrm{n}$ & $\mathrm{x} \pm \Sigma \Delta$ & $\mathrm{p}$ \\
\hline Central on D-1 & & & \\
$\quad$ Artificial tears & 20 & $245.75 \pm 34.469$ & 0.721 \\
$\quad$ Diclofenac sodium & 20 & $248.85 \pm 17.101$ & \\
Inner on D-1 & & & 0.386 \\
$\quad$ Artificial tears & 20 & $302.95 \pm 46.440$ & \\
$\quad$ Diclofenac sodium & 20 & $312.70 \pm 16.874$ & 0.688 \\
Outer on D-1 & & & \\
$\quad$ Artificial tears & 20 & $273.85 \pm 31.925$ & \\
$\quad$ Diclofenac sodium & 20 & $277.00 \pm 13.765$ & \\
\hline
\end{tabular}


Patients treated with diclofenac sodium before and after cataract surgery had lower levels of intraocular interleukin-12 and may reduce the incidence of postoperative macular edema in patients with DR [13].

Table 6: Changes in macular thickness in D - 1, D + 14, and D + 30 control group

\begin{tabular}{|c|c|c|c|}
\hline Thickness macula & $\mathrm{n}$ & $x \pm \Sigma \Delta$ & $p$ \\
\hline \multicolumn{4}{|l|}{ Central } \\
\hline On D - 1 & 20 & $245.75 \pm 34.469$ & \multirow[t]{2}{*}{0.937} \\
\hline On $\mathrm{D}+14$ & 20 & $245.40 \pm 22.883$ & \\
\hline \multicolumn{4}{|l|}{ Inner } \\
\hline On D - 1 & 20 & $302.95 \pm 46.440$ & \multirow[t]{2}{*}{0.946} \\
\hline On D + 14 & 20 & $302.60 \pm 31.426$ & \\
\hline \multicolumn{4}{|l|}{ Outer } \\
\hline On D - 1 & 20 & $273.85 \pm 31.925$ & \multirow[t]{2}{*}{0.571} \\
\hline On D + 14 & 20 & $276.65 \pm 21.902$ & \\
\hline \multicolumn{4}{|l|}{ Central } \\
\hline On $\mathrm{D}+14$ & 20 & $245.40 \pm 22.883$ & \multirow[t]{2}{*}{0.247} \\
\hline On $\mathrm{D}+30$ & 20 & $241.30 \pm 19.027$ & \\
\hline \multicolumn{4}{|l|}{ Inner } \\
\hline On D + 14 & 20 & $302.60 \pm 31.426$ & \multirow[t]{2}{*}{0.895} \\
\hline On D +30 & 20 & $301.80 \pm 14.609$ & \\
\hline \multicolumn{4}{|l|}{ Outer } \\
\hline On D + 14 & 20 & $276.65 \pm 21.902$ & \multirow[t]{2}{*}{0.711} \\
\hline On D + 30 & 20 & $278.55 \pm 14.497$ & \\
\hline
\end{tabular}

Meanwhile, the outer macular thickness before surgery and 14 days after surgery show a $p>0.05$, which means that there is no statistically significant difference. The same result can also be found in central, inner, outer macular thickness in 14 days and 30 days after the surgery.

Table 7: Changes in Macular Thickness in D-1, D + 14, and D + 30 treatment group

\begin{tabular}{llll}
\hline Macular thickness & $\mathrm{n}$ & $\mathrm{x} \pm \Sigma \Delta$ & $\mathrm{p}$ \\
\hline Central & & & \\
On D - 1 & 20 & $248.85 \pm 17.101$ & 0.008 * \\
On D + 14 & 20 & $241.80 \pm 19.632$ & \\
Inner & 20 & $312705 \pm 16.874$ & $0.0001^{*}$ \\
On D - 1 & & & \\
On D + 14 & 20 & $300.35 \pm 15.786$ & 0.490 \\
Outer & & & \\
On D - 1 & 20 & $277.00 \pm 13.765$ & 0.133 \\
On D + 14 & 20 & $279.55 \pm 16.669$ & \\
Central & & & \\
On D + 14 & 20 & $241.80 \pm 19.632$ & \\
On D + 30 & 20 & $236.55 \pm 14.713$ & \\
Inner & & & \\
On D + 14 & 20 & $300.35 \pm 15.786$ & \\
On D + 30 & 20 & $295.60 \pm 18.112$ & \\
Outer & & & \\
On D + 14 & 20 & $279.55 \pm 16.669$ & \\
On D +30 & 20 & $271.50 \pm 13.271$ & \\
\hline
\end{tabular}

It is known that the energy generated by phacoemulsification does not affect changes in the thickness of the retina as well as the macula (Figures 1 and 2). This is also in accordance with Liu's research in 2015 which stated that inappropriate selection of phacoemulsification type will affect the thickening of the macula, especially in mild-to-moderate NPDR patients [14], [15].

Mentes' study in 2003 stated the incidence of CME after phacoemulsification surgery, it was reported that 23 out of 252 eyes experienced CME angiography and disappeared after being evaluated for 45 days [16].

The use of topical NSAIDs may reduce the risk of developing macular edema after cataract surgery, although there is still much debate about clinical uncertainty regarding the benefits of administering topical NSAIDs as prophylaxis. In addition, research done by Kessel in 2014 stated that topical NSAIDs are more effective in controlling postoperative inflammation after cataract surgery, especially regarding macular edema compared to the use of topical steroids, so there is no harm in continuing to provide regular topical NSAIDs such as diclofenac sodium to prevent inflammation and macular edema in post-cataract surgery [17].

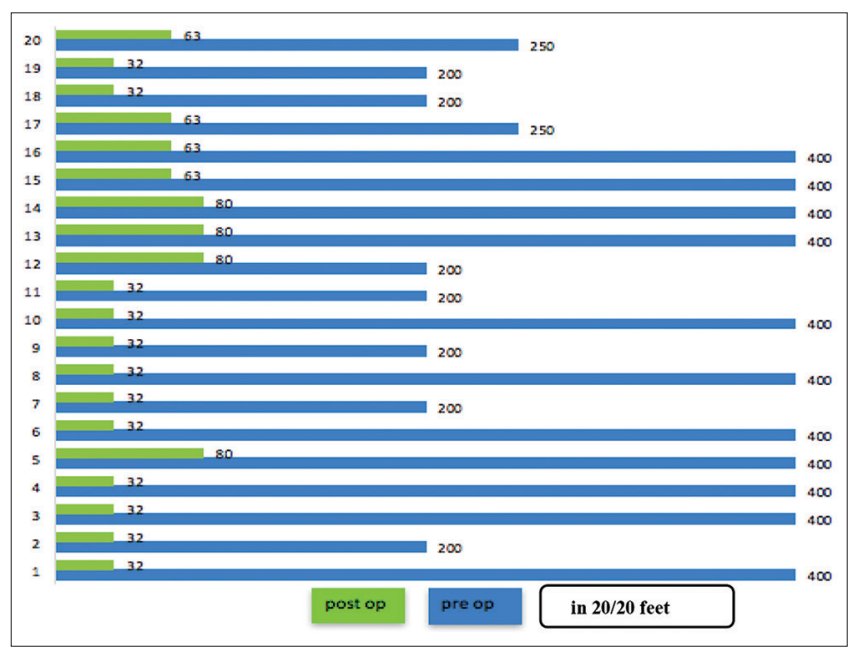

Figure 1: Results of pre- and post-cataract surgery virus research subjects control group

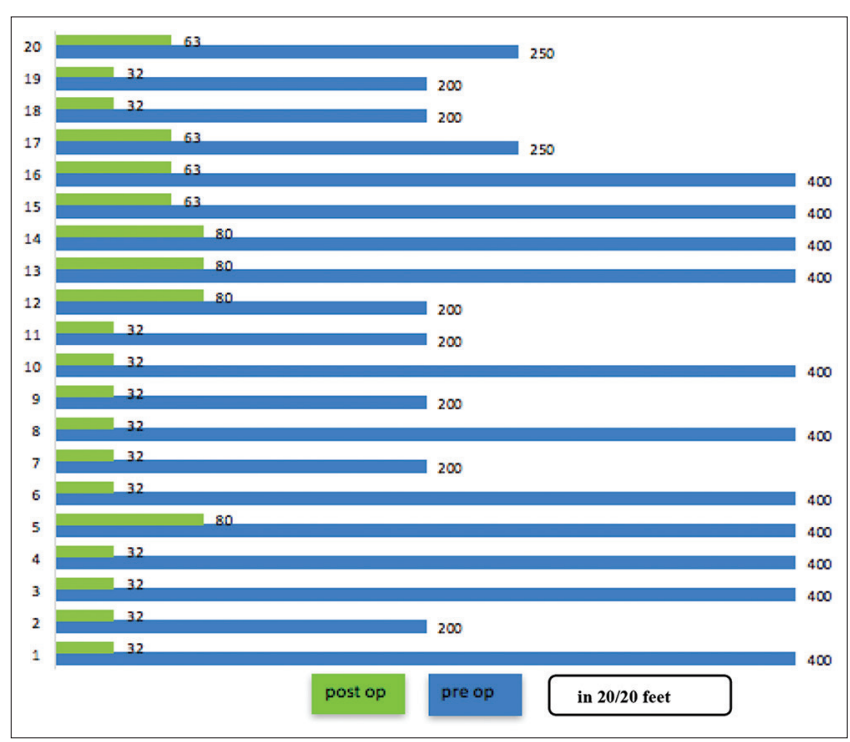

Figure 2: Results of pre- and post-cataract surgery virus research subjecs treatment group

\section{Conclusion}

There were significant changes in central and inner macular thickness during observation 1 day before surgery until 14 days in the diclofenac sodium group. Moreover, there were no significant changes in central, inner, and outer macular thickness during observation 
14-30 days postoperatively in the diclofenac sodium group.

\section{References}

1. Kasper DL, Fauci AS, Hauser SL, Longo DL, Loscalzo J. Harrison's Principles of Internal Medicine. $19^{\text {th }}$ ed. New York: McGraw-Hill Education; 2015.

2. Balitbang Kemenkes RI. Riset Kesehatan Dasar RISKESDAS. Jakarta: Balitbang Kemenkes RI; 2013. https://doi.org/10.32922/ jkp.v8i2

3. Ilyas S, Tansil M, Salamun ZA. Sari IImu Penyakit Mata. Jakarta: Balai Penerbit FK UI; 2000.

4. Vaughan D, Asbury T, Riordan-Eva P, Whitcher JP. Vaughan and Asbury: Oftalmologi Umum. $17^{\text {th }}$ ed. Jakarta: Penerbit Buku Kedokteran EGC; 2015.

5. Lobo C. Pseudophakic cystoid macular edema. Ophthalmologica. 2012;227(2):61-7. https://doi.org/10.1159/000331277 PMid:21921587

6. Wielders LH, Schouten JS, Winkens B, van den Biggelaar FJ, Veldhuizen CA, Murta JC, et al. Randomized controlled European multicenter trial on the prevention of cystoid macular edema after cataract surgery in diabetics: ESCRS PREMED study report 2. J Cataract Refract Surg. 2018;44(7):836-47. https://doi.org/10.1016/j.jcrs.2018.05.015

PMid:30055692

7. Almeida DR, Khan Z, Xing L, Bakar SN, Rahim K, Urton T, et al. Prophylactic nepafenac and ketorolac versus placebo in preventing postoperative macular edema after uneventful phacoemulsification. J Cataract Refract Surg. 2012;38(9):153743. https://doi.org/10.1016/j.jcrs.2012.04.034 PMid:22795976

8. Kim SJ, Flach AJ, Jampol LM. Nonsteroidal anti-inflammatory drugs in ophthalmology. Surv Ophthalmol. 2010;55(2):108-33. PMid:20159228

9. Kiziltoprak H, Tekin K, Inanc M, Goker YS. Cataract in diabetes mellitus. World J Diabetes. 2019;10(3):140-53. https://doi. org/10.4239/wjd.v10.i3.140 PMid:30891150

10. Becker C, Schneider C, Aballea S, Bailey C, Bourne R, Jick S, Meier C. Cataract in patients with diabetes mellitus-incidence rates in the UK and risk factors. Eye (Lond). 2016;32(6):102835. https://doi.org/10.1038/s41433-017-0003-1

PMid:29386666

11. Walkden A, Porter LF, Morarji J, Kelly SP, Sioras E. Pseudophakic cystoid macular edema and spectral-domain optical coherence tomography-detectable central macular thickness changes with perioperative prostaglandin analogs. J Cataract Refract Surg. 2017;43(8):1027-30. https://doi.org/10.1016/j.jcrs.2017.05.029 PMid:28917401

12. Bellocq D, Mathis T, Voirin N, Bentaleb ZM, Sallit R, Denis $P$, Kodjikian L. Incidence of irvine gass syndrome after phacoemulsification with spectral-domain optical coherence tomography. Ocul Immunol Inflamm. 2019;27(8):1224-31. https://doi.org/10.1080/09273948.2019.1634215 PMid:31414913

13. Medic A, Jukic T, Matas A, Vukojević K, Sapunar A, Znaor L. Effect of preoperative topical diclofenac on intraocular interleukin-12 concentration and macular edema after cataract surgery in patients with diabetic retinopathy: A randomized controlled trial. Croat Med J. 2017;58(1):49-55. https://doi. org/10.3325/cmj.2017.58.49 PMid:28252875

14. Georgopoulos GT, Papaconstantinou D, Niskopoulou M, Moschos M, Georgalas I, Koutsandrea C. Foveal thickness after phacoemulsification as measured by optical coherence tomography. Clin Ophthalmol. 2008;2(4):817-20. https://doi. org/10.2147/opth.s4031 PMid:19668435

15. Liu J, Jones RE, Zhao J, Zhang J, Zhang F. Influence of uncomplicated phacoemulsification on central macular thickness in diabetic patients: A meta-analysis. PLoS One. 2015;10(5):e0126343.https://doi.org/10.1371/journal. pone. 0126343 PMid:25965404

16. Mentes J, Erakgun T, Afrashi F, Kerci G. Incidence of cystoid macular edema after uncomplicated phacoemulsification. Ophthalmologica. 2003;217(6):408-12. https://doi. org/10.1159/000073070 PMid: 14573973

17. Kessel L, Tendal B, Jorgensen KJ, Erngaard D, Flesner $P$, Andresen $\mathrm{JL}$, et al. Post-cataract prevention of inflammation and macular edema by steroid and nonsteroidal anti-inflammatory eye drops: A systematic review. Ophthalmology. 2014;121(10):191524. https://doi.org/10.1016/j.ophtha.2014.04.035 PMid:24935281 